\title{
Hubungan Kemampuan Berpikir Kreatif Terhadap Hasil Belajar Mahasiswa
}

\author{
Arie Wahyuni, Prihadi Kurniawan \\ Pendidikan Matematika, Fakultas Pendidikan Teknologi dan Kejuruan, \\ IKIP Veteran Jawa Tengah, Semarang, Indonesia \\ ariewahyuni11@ikip-veteran.ac.id, kurniawan.prihadi@ikip-veteran.ac.id
}

\begin{abstract}
Abstrak. Perguruan tinggi sekarang ini sangat ditekankan dalam proses pembelajaran hendaknya mahasiswa memiliki kemampuan berpikir kreatif. Kemampuan berpikir kreatif memiliki kecenderungan dapat melatih mahasiswa untuk mengeluarkan ide-ide yang muncul atau mengekspresikan diri dalam proses pembelajaran. Tujuan dari penelitian ini adalah untuk mengetahui adakah pengaruh kemampuan berpikir kreatif terhadap hasil belajar mahasiswa dan seberapa besarkah pengaruh kemampuan berpikir kreatif terhadap hasil belajar mahasiswa. Metode yang digunakan dalam penelitian ini adalah kuantitatif deskriptif dengan analisis regresi linear. Analisis data dengan menghitung koefisien korelasi dan uji signifikan nya kemudian dilanjutkan dengan menentukan persamaan regresinya. Hasil penelitian menunjukkan bahwa kemampuan berpikir kreatif mempengaruhi hasil belajar mahasiswa dengan nilai tidak signifikan serta kemampuan berpikir kreatif mempengaruhi hasil belajar mahasiswa sebesar 22,5\%.
\end{abstract}

Kata Kunci: pengaruh, kemampuan berpikir kreatif, hasil belajar.

Abstract. (The Corellation of Creative Thinking Ability and Student Learning Outcomes). Today's universities are highly emphasized in the learning process students should have the ability to think creatively. The ability to think creatively has a tendency to train students to issue ideas that emerge or express themselves in the learning process. The purpose of this research is to find out is there any influence of the ability to think creatively on student learning outcomes and how much influence the ability to think creatively on student learning outcomes. The method used in this study is quantitative descriptive with linear regression analysis. Data analysis by calculating the correlation coefficient and significant test then followed by determining the regression equation. The results showed that creative thinking ability influenced student learning outcomes with insignificant values and creative thinking ability influenced student learning outcomes by $22.5 \%$.

Keywords: Influence, Creative Thinking Skills, Learning Outcomes.

\section{Pendahuluan}

Perguruan tinggi sekarang ini sangat ditekankan dalam proses pembelajaran, hendaknya mahasiswa memiliki kemampuan berpikir kreatif. Kemampuan berpikir kreatif memiliki kecenderungan dapat melatih mahasiswa untuk mengeluarkan ide-ide yang muncul atau mengekspresikan diri dalam proses pembelajaran. Proses pembelajaran terdiri dari dua kegiatan yaitu kegiatan di luar kelas dibantu komputer dan kegiatan pembelajaran kelompok interaktif di dalam kelas [7, 27]. Menurut Wahyuni [24], pembelajaran merupakan aktivitas siswa dalam memahami hubungan, norma, serta symbol. Pembelajaran yang dilakukan berupa kegiatan di dalam atau di luar kelas, hendaknya memunculkan pembelajaran yang sangat menarik sehingga mahasiswa memiliki kemampuan yang interaktif, inovatif dan kreatif. Menurut Baroody [6], pembelajaran setidaknya dapat membantu siswa dalam 5 aspek diantaranya adalah representing, listening, reading, discussing, dan writing. Menurut Ahmad [2], pembelajaran harus mampu mengacu pada 4 konsep belajar yaitu belajar mengetahui, belajar melakukan, belajar menjadi, dan belajar bekerjasama. Belajar mengetahui yang dimaksud adalah, dosen sebagai fasilitator bagi mahasiswa setidaknya dapat mengembangkan kemampuan berpikir kreatif mahasiswa, belajar melakukan sesuatu artinya mahasiswa diberi kesempatan oleh dosen dalam melakukan keterampilan, belajar menjadi seseorang yang dimaksud adalah dosen memberi kesempatan 
mahasiswa dalam memaksimalkan kemampuan berpikir kreatif yang aktif, dan belajar bekerjasama artinya dalam melakukan sesuatu hal saling bekerjasama dan saling menghargai. Konsep-konsep belajar tersebut sangat penting dalam pembelajaran sehingga dapat membuat mahasiswa memiliki percaya diri yang kuat dan memiliki daya pesaing yang hebat. Pelatihan dapat meningkatkan kinerja pada tugastugas yang diberikan saat pembelajaran [23, 26]. Menurut Sanjaya [20], pembelajaran merupakan suatu sistem yang kompleks dapat dilihat dua aspek yakni aspek produk dan aspek proses, sedangkan menurut Isjoni [11], pembelajaran adalah sesuatu yang melakukan siswa tetapi bukan dibuat untuk siswa. Sehingga dari pendapat di atas dapat disimpulkan oleh peneliti bahwa pembelajaran adalah suatu sistem yang memiliki dua aspek yakni aspek produk dan aspek proses dimana yang melakukan siswa tetapi bukan dibuat untuk siswa.

Matematika memiliki peran penting untuk membekali mahasiswa dengan kemampuan berpikir kreatif, logis, analitik, sistematik, dan komunikasi matematis. Berpikir kreatif adalah kelancaran, keluwesan, keaslian (originalitas), dan merinci (elaborasi) [10, 28], sedangkan menurut Sumarmo [21], kreativitas merupakan kemampuan untuk memberikan ide-ide baru. Menurut Meika [15], kemampuan berpikir merupakan kemampuan dengan kreativitas dengan cara berpikir, dan menurut Ersoy [9], berpikir kreatif merupakan salah satu keterampilan berpikir yang memfasilitasi pembelajaran individu dengan merealisasikan imajinasinya, memberikan kesempatan baginya untuk berpikir. Dari pendapatpendapat di atas dapat disimpulkan kemampuan berpikir kreatif merupakan kemampuan yang memberikan ide-ide baru dengan cara berpikir dan merealisasikan imajinasinya serta memberikan kesempatan bagi mahasiswa sesuai dengan kelancaran, keluwesan, keaslian/originalitas dan merinci/elaborasi. Adapun ciri-ciri kreativitas diantaranya adalah: ciri kognitif dan ciri non kognitif [17]. Bentuk perilaku dari berpikir kreatif pada penelitian ini sebagai berikut.

Tabel 1. Perilaku Kemampuan Berpikir Kreatif

\begin{tabular}{|l|l|}
\hline Indikator & Perilaku \\
\hline Kelancaran & Kemampuan menghasilkan banyak gagasan \\
\hline Kerincian & $\begin{array}{l}\text { Kemampuan merinci detail, kemampuan memiliki } \\
\text { gagasan yang luas }\end{array}$ \\
\hline Fleksibilitas & Kemampuan memberikan arah pemikiran yang berbeda \\
\hline Orisinalitas & Kemampuan memberikan arah pemikiran yang berbeda \\
\hline
\end{tabular}

Pengembangan kemampuan merupakan tujuan dari pendidikan nasional, salah satunya kemampuan berpikir kreatif. Tugas utama pendidikan adalah menciptakan orang yang mampu melakukan sesuatu yang baru [16]. Menurut Mahmudi [14], pentingnya kemampuan berpikir kreatif karena salah satu kemampuan dalam dunia kerja. Dalam hal ini rendahnya kemampuan berpikir kreatif dapat ditunjukkan dari hasil jawaban soal kemampuan berpikir kreatif yang peneliti lakukan ketika saat mengambil data awal. Pada proses pembelajaran, dosen jarang atau tidak pernah mengarah pada kemampuan berpikir kreatif. Dosen sebenarnya selama ini dalam proses pembelajaran sudah baik, tetapi dosen kurang memperhatikan kegiatan belajar mahasiswa yang mengarah pada proses berpikir kreatif. Dosen berperan penting dalam hal keberhasilan belajar mahasiswa, dosen tidak hanya mentransfer pengetahuan tetapi dosen juga memfasilitasi kegiatan belajar agar mahasiswa dapat aktif dalam mengikuti pembelajaran. Belajar kreatif merupakan salah satu budaya dan karakter bangsa. Belajar kreatif juga penting dalam peningkatan mutu pembelajaran, sehingga kreativitas merupakan kompetensi dalam hal proses dan hasil belajar. Berdasarkan penelitian, Edi [8] mengatakan bahwa siswa yang memiliki kreativitas tinggi hasil belajarnya lebih tinggi dibandingkan siswa yang memiliki kreativitas rendah.

Belajar adalah perubahan serta peningkatan kualitas dan kuantitas tingkah laku seseorang yang terjadi akibat adanya interaksi [13]. Menurut Sutikno [22], belajar merupakan proses usaha yang dilakukan seseorang dalam interaksi dengan lingkungannya, sehingga menurut pendapat-pendapat di atas, belajar merupakan proses usaha yang dilakukan seseorang dalam peningkatan kualitas dan kuantitas tingkah laku pada interaksi dengan lingkungannya. Mahasiswa setelah berusaha atau berupaya 
dalam proses belajar, setidaknya akan memiliki hasil belajar. Hasil belajar adalah hasil yang telah dicapai oleh seseorang setelah melakukan kegiatan belajar dalam aspek kognitif, afektif, dan psikomotorik, yang dinyatakan simbol, angka dan tulisan [18]. Menurut Lahir [13], hasil belajar adalah prestasi belajar dalam proses belajar dengan membawa perubahan dan sikap perilaku seseorang, sedangkan menurut Suprijono [1], hasil belajar adalah pola perubahan, sikap, dan keterampilan. Dari pendapat-pendapat di atas maka dapat peneliti simpulkan bahwa hasil belajar merupakan hasil yang diperoleh seseorang atau pola perubahan dan sikap seseorang setelah melakukan kegiatan belajar dalam aspek kognitif, afektif dan psikomotorik yang dinyatakan dalam symbol, angka dan tulisan. Adapun faktor-faktor hasil belajar diantaranya adalah faktor internal dan faktor eksternal [19]. Dalam hal ini, semua faktor internal maupun faktor eksternal sangat mendukung dalam hasil belajar seseorang dikarenakan faktor internal dan faktor eksternal saling berkaitan satu dengan yang lain.

\section{Metode Penelitian}

Jenis penelitian yang dilakukan terhadap pembahasan pada artikel ini adalah penelitian kuantitatif deskriptif dengan disain One-shot case study. Menurut Sugiyono [3], penelitian kuantitatif merupakan penelitian yang berlandaskan pengumpulan data menggunakan instrumen penelitian dengan tujuan untuk menguji hipotesis yang telah ditetapkan. Menurut [25] penelitian deskriptif yaitu penelitian yang dilakukan untuk mengetahui nilai variabel mandiri, baik satu variabel atau lebih. Sehingga penelitian kuantitatif deskriptif merupakan data yang diperoleh dari sampel populasi penelitian dianalisis sesuai dengan metode statistik yang digunakan. Disain One-shot study adalah perlakuan tertentu pada suatu kelompok subjek kemudian dilakukan pengukuran terhadap variabel terikat [4]. Pola desain One-shot study adalah sebagai berikut:

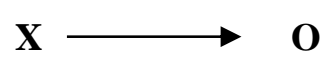

Keterangan:

$X$ : Treatment atau perlakuan

$\mathrm{O}$ : Hasil akhir sesudah treatment (perlakuan)

Subyek penelitian dilakukan pada mahasiswa semester 2 tahun pelajaran 2017/2018 IKIP Veteran Jawa Tengah dengan sampel pada penelitian berjumlah 11 mahasiswa. Instrumen yang digunakan adalah tes hasil belajar dan data kemampuan berpikir kreatif diperoleh dengan menggunakan lembar observasi. Tes hasil belajar terlebih dahulu dilakukan uji validitas, reliabilitas, daya beda, dan tingkat kesukaran. Dalam pengumpulan data, langkah-langkah yang dilakukan peneliti antara lain mempersiapkan instrumen, menentukan subyek penelitian, dan melakukan pembelajaran sesuai dengan disain. Selama proses pembelajaran observer melakukan observasi kreativitas kepada mahasiswa.

\section{a. Uji validitas [5]}

$$
r_{x y}=\frac{N \sum x y-\left(\sum x\right)\left(\sum y\right)}{\sqrt{\left\{N \sum x^{2}-\left(\sum x\right)^{2}\right\}\left\{N \sum y^{2}-\left(\sum y\right)^{2}\right\}}}
$$

Keterangan:

$r_{x y}=$ koefisien korelasi antara $\mathrm{x}$ dan $\mathrm{y}$.

$N=$ jumlah siswa.

$x=$ skor butir soal (item).

$y \quad=$ skor total butir soal. 
Setelah dihitung $r$ dibandingkan dengan $r_{\text {tabel }}$ (r-product moment) dengan taraf signifikansi 5\%, jika $r_{\text {hitung }}>r_{\text {tabel }}$ maka dikatakan soal valid.

b. Uji reliabilitas [5]

$$
r_{11}=\left(\frac{n}{n-1}\right)\left(1-\frac{\sum \sigma_{i}^{2}}{\sigma_{t}^{2}}\right)
$$

Keterangan:

$r_{11} \quad=$ reliabilitas yang dicari.

$\sum \sigma_{i}{ }^{2}=$ jumlah varians skor tiap-tiap item

$\sigma_{t}^{2} \quad=$ varians total

Kriteria:

$0,80<\mathrm{r}_{11} \leq 1,00=$ Reabilitas sangat tinggi;

$0,60<\mathrm{r}_{11} \leq 0,80=$ Reabilitas tinggi;

$0,40<\mathrm{r}_{11} \leq 0,60=$ Reabilitas sedang;

$0,20<\mathrm{r}_{11} \leq 0,40=$ Reabilitas rendah.

\section{c. Daya beda}

Rumus daya pembeda butir soal [12]:

$$
D P=\frac{S A-S B}{\frac{1}{2} \times N \times M a k s}
$$

DP = Daya Pembeda;

$\mathrm{SA}=$ Jumlah skor yang dicapai siswa kelompok atas;

$\mathrm{SB}=$ Jumlah skor yang dicapai siswa kelompok bawah;

$\mathrm{N}$ = Jumlah siswa dari kelompok atas dan kelompok bawah;

Maks $=$ Skor maksimal soal .

Kriteria:

$0.0<\mathrm{DP} \leq 0.20=$ Jelek;

$0.20<\mathrm{DP} \leq 0.40=$ Cukup;

$0.40<\mathrm{DP} \leq 0.70=$ Baik;

$0.70<\mathrm{DP} \leq 1.00=$ Sangat Baik.

\section{d. Tingkat kesukaran}

Rumus tingkat kesukaran butir soal (Jihad \& Haris, 2009):

$$
I K=\frac{S A+S B}{N \times M a k s}
$$

IK = Indeks Kesukaran;

SA = Jumlah skor yang dicapai siswa kelompok atas;

$\mathrm{SB}=$ Jumlah skor yang dicapai siswa kelompok bawah;

$\mathrm{N}$ = Jumlah siswa dari kelompok atas dan kelompok bawah; 
Maks $=$ Skor maksimal soal

Kriteria:

$0,00<\mathrm{IK} \leq 0,30=$ Sukar;

$0,30<\mathrm{IK} \leq 0,70=$ Sedang;

$0,70<\mathrm{IK} \leq 1,00=$ Mudah.

Butir soal yang baik bila termasuk dalam kriteria sedang. Bila termasuk kriteria sukar atau mudah maka akan direvisi.

Data dalam penelitian yang diperoleh berupa hasil belajar dan data kemampuan berpikir kreatif dalam proses pembelajaran. Pengujian hipotesis yang digunakan untuk mengetahui hubungan kemampuan berpikir kreatif dengan hasil belajar dan pengaruh kemampuan berpikir kreatif dengan hasil belajar Matematika yang digunakan analisis korelasi dan uji regresi linear dengan program SPSS 16.

\section{Hasil dan Pembahasan}

a. Analisis instrumen

Instrumen yang digunakan dalam penelitian ini telah memenuhi persyaratan dan analisis selanjutnya pada tingkat kesukaran dan daya pembeda soal sudah memenuhi sebagai instrumen. Uji hubungan dan pengaruh dalam penelitian ini akan dilakukan uji regresi dengan menggunakan SPSS 16.

b. Deskripsi hasil penelitian

Data yang digunakan pada penelitian ini adalah hasil belajar mahasiswa serta data hasil observasi kemampuan berpikir kreatif pada proses pembelajaran. Data hasil belajar dan kemampuan berpikir kreatif sebagai berikut.

1) Hasil belajar

Adapun hasil belajar yang diperoleh nilai rata-rata (mean) $=82,9091$ dan standar deviasi (standar deviation) $=5,95742$.

2) Kemampuan berpikir kreatif

Adapun nilai rata-rata (mean) dari kemampuan berpikir kreatif $=86,4545$ dan standar deviasi kemampuan berpikir kreatif $=6,34608$.

Tabel 2. Hasil Statistika Antara Hasil Belajar dan Kemampuan Berpikir Kreatif

\section{Descriptive Statistics}

\begin{tabular}{|l|l|r|r|}
\hline & Mean & Std. Deviation & \multicolumn{1}{|c|}{$\mathrm{N}$} \\
\hline $\begin{array}{l}\text { KemampuanBerpikirKrea } \\
\text { tif }\end{array}$ & 82.9091 & 5.95742 & 11 \\
HasilBelajar & 86.4545 & 6.34608 & 11 \\
\hline
\end{tabular}

3) Uji hipotesis

Analisis data dengan menghitung koefisien korelasi dan uji signifikannya kemudian dilanjutkan dengan menentukan persamaan regresinya, dalam perhitungan penelitian ini menggunakan SPSS 16 agar dapat mengetahui hubungan kemampuan berpikir kreatif terhadap hasil belajar mahasiswa dan pengaruh kemampuan berpikir kreatif terhadap hasil belajar mahasiswa dan seberapa besar pengaruh kemampuan berpikir kreatif terhadap hasil belajar mahasiswa. 
Hipotesis pertama:

Tabel 3. Uji Hubungan Kemampuan Berpikir Kreatif Terhadap Hasil Belajar

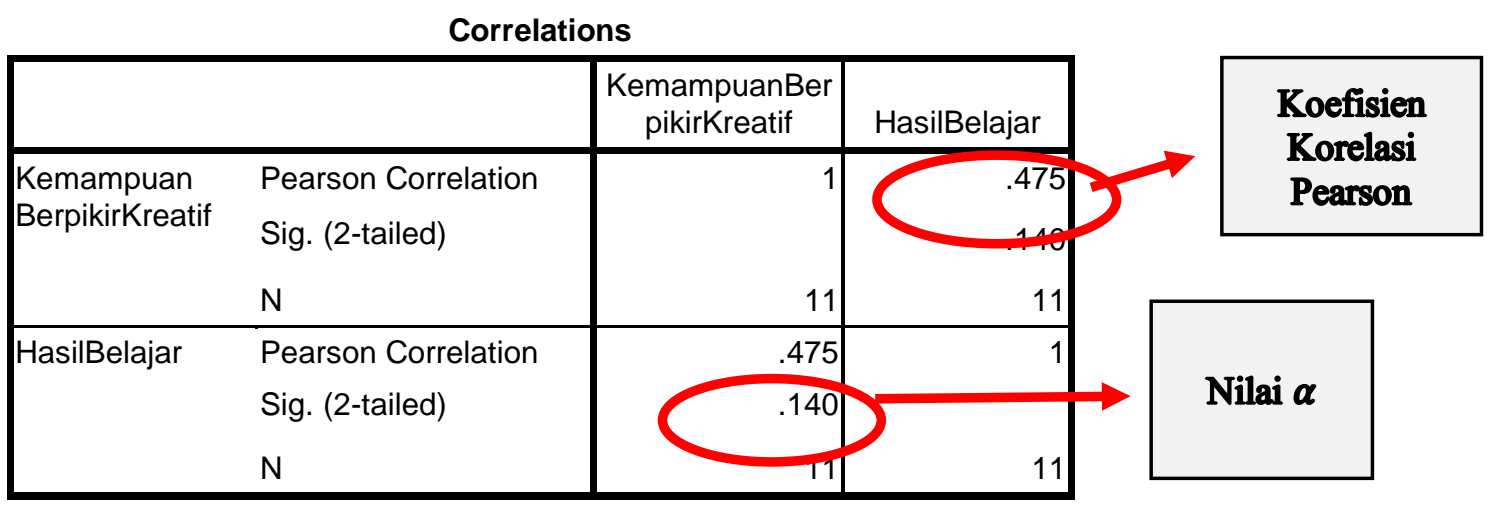

\section{Signifikan hasil korelasi}

Hipotesis:

$\mathrm{H}_{0}$ : Tidak ada hubungan antara kemampuan berpikir kreatif dan hasil belajar $\mathrm{H}_{\mathrm{a}}$ : Ada hubungan antara kemampuan berpikir kreatif dan hasil belajar.

Dasar pengambilan keputusan:

Jika probabilitasnya $>0,05$ maka $\mathrm{H}_{0}$ diterima

Jika probabilitasnya $<0,05$ maka $\mathrm{H}_{0}$ ditolak

Diperoleh $\alpha=0,140>0,05$ sehingga $\mathrm{H}_{0}$ diterima.

Jadi, tidak ada hubungan antara kemampuan berpikir kreatif dan hasil belajar.

Kesimpulan:

Koefisien korelasi yang ditemukan signifikan, yaitu dapat digeneralisasikan ke seluruh sampel yang diambil.

\section{Hipotesis kedua:}

\section{Tabel 4. Koefisien determinasi}

Model Summary

\begin{tabular}{|c|c|c|c|c|c|c|c|c|c|}
\hline \multirow[b]{2}{*}{ Model } & \multirow[b]{2}{*}{$\mathrm{R}$} & \multirow[b]{2}{*}{ Square } & \multirow[b]{2}{*}{$\begin{array}{c}\text { Adjusted } R \\
\text { Square }\end{array}$} & \multirow{2}{*}{$\begin{array}{l}\text { Std. Error } \\
\text { of the } \\
\text { Estimate }\end{array}$} & \multicolumn{5}{|c|}{ Change Statistics } \\
\hline & & & & & $\begin{array}{l}\text { R Square } \\
\text { Change }\end{array}$ & F Change & df1 & $\mathrm{df} 2$ & $\begin{array}{l}\text { Sig. F } \\
\text { Change }\end{array}$ \\
\hline 1 & $.475^{\mathrm{a}}$ & .225 & .139 & 5.88773 & .225 & 2.618 & 1 & 9 & .140 \\
\hline
\end{tabular}

a. Predictors: (Constant), KemampuanBerpikirKreatif

b. Dependent Variable: HasilBelajar

Uji lanjut dilakukan untuk mengetahui seberapa besar pengaruh kemampuan berpikir kreatif terhadap hasil belajar mahasiswa. Pengujian dengan uji regresi dilakukan menggunakan SPSS dan menunjukkan hasil seperti tabel 4. Hasil pengujian menunjukkan skor R square atau koefisien determinasi sebesar 0,225 yang artinya kemampuan berpikir kreatif mempengaruhi hasil belajar mahasiswa sebesar $22,5 \%$, sedangkan sisanya dipengaruhi oleh faktor lain yang tidak terukur dalam penelitian ini. 
Hipotesis ketiga:

Tabel 5. Uji Pengaruh Kemampuan Berpikir Kreatif Terhadap Hasil Belajar

\begin{tabular}{|c|c|c|c|c|c|}
\hline \multicolumn{6}{|c|}{ Coefficients $^{\mathrm{a}}$} \\
\hline \multirow[b]{2}{*}{ Model } & \multicolumn{2}{|c|}{ Unstandardized Coefficients } & $\begin{array}{l}\text { Standardized } \\
\text { Coefficients }\end{array}$ & \multirow[b]{2}{*}{$\mathrm{t}$} & \multirow[b]{2}{*}{ Sig. } \\
\hline & B & Std. Error & Beta & & \\
\hline $1 \quad$ (Constant) & 44.533 & 25.972 & & 1.715 & .121 \\
\hline $\begin{array}{l}\text { KemampuanBerpi } \\
\text { kirKreatif }\end{array}$ & .506 & .313 & .475 & 1.618 & .140 \\
\hline
\end{tabular}

${ }^{a}$ Dependent Variable: HasilBelajar

Pada tabel 5 diatas dapat menunjukkan persamaan regresi dari variabel kemampuan berpikir kreatif dan hasil belajar mahasiswa. Diperoleh persamaan regresi $\mathrm{Y}=44,533+0,506 \mathrm{x}$, artinya setiap penambahan variabel kemampuan berpikir kreatif sebesar satu satuan, maka variabel hasil belajar mahasiswa bertambah sebesar 0,506 satuan.

\section{Kesimpulan}

Hasil penelitian menunjukkan bahwa tidak terdapat korelasi antara kemampuan berpikir kreatif dan hasil belajar mahasiswa, dan kemampuan berpikir kreatif mempengaruhi hasil belajar mahasiswa dengan nilai tidak signifikan, serta kemampuan berpikir kreatif mempengaruhi hasil belajar mahasiswa sebesar $22,5 \%$. Sedangkan sisanya dipengaruhi oleh faktor-faktor lain yang tidak terukur dalam penelitian ini.

\section{Referensi}

[1] Agus Suprijono, Cooperative Learning Teori \& Aplikasi Paikem, Yogyakarta: Pustaka Pelajar, 2011.

[2] Ahmad Susanto, M.P., Teori Belajar dan Pembelajaran di Sekolah Dasar, Kencana, 2016.

[3] Sugiyono, Metode Penelitian Kuantitatif, Kualitatif dan R\&D. Bandung: Alfabeta, 2012.

[4] Arikunto, S., Prosedur Penelitian Suatu Pendekatan Praktik. Jakarta: Rineka Cipta. 2006.

[5] Arikunto, S., Dasar-Dasar Evaluasi Pendidikan (Edisi Revisi). Jakarta: PT. Bumi Aksara. 2009.

[6] Baroody. A.J., Problem Solving, Reasoning, and Communicating, New York: Macmillan Publishing, 1993.

[7] Bishop, J., \& Verleger, M. (2013). Testing The Flipped Classroom With Model-Eliciting Activities And Video Lectures In A Mid-Level Under Graduate Engineering Course. In IEEE Frontiers In Education conference. 2013. pp. 161-163.

[8] Edi, J. Pengaruh Model Pembelajaran dan Kreativitas Terhadap Hasil Belajar Kimia SMA. Tesis, Program Pasca Sarjana, Universitas Negeri Medan. 2004.

[9] Ersoy, E., The Effects Of Problem-Based Learning Method In Higher Education On Creative Thinking. Procedia-Social and Behavioral Sciences, Vol. 116, 2014. pp. 3494-3498.

[10] Fauziah. Analisis Kemampuan Guru Dalam Mengembangkan Keterampilan Berpikir Kreatif Siswa Sekolah Dasar Kelas V Pada Pembelajaran Ilmu Pengetahuan Alam. Edisi Khusus No. 2, 2011. ISSN 1412-565x

[11] Isjoni., Pembelajaran Kooperatif Meningkatkan Kecerdasan Komunikasi Antar Peserta Didik. Yogyakarta: Pustaka Pelajar, 2011.

[12] Jihad \& Haris., Evaluasi Pembelajaran. Yogyakarta: Multi Pressindo. 2009. 
[13] Lahir, S., Ma'aruf, M.H., \& Tho'in, M., Peningkatan Prestasi Belajar Melalui Model Pembelajaran Yang Tepat Pada Sekolah Dasar Sampai Perguruan Tinggi. Jurnal Ilmiah Edunomika, 1 (01). 2017.

[14] Mahmudi, A., Mengukur Kemampuan Berpikir Kreatif Matematis. Makalah. Konferensi Nasional Matematika XV UNIMA, 30 Juni-3 Juli 2010.

[15] Meika, I., \& Sujana, A., Kemampuan Berpikir Kreatif dan Pemecahan Masalah Matematis Siswa SMA. Jurnal Penelitian dan Pembelajaran Matematika, 10(2). 2017.

[16] Mulyasa, E., Kurikulum Berbasis Kompetensi: Konsep, Karakteristik, Implementasi, dan Inovasi. Bandung: PT Remaja Rosdakarya Offset. 2006.

[17] Munandar, Pengembangan Kreativitas Anak Berbakat. Jakarta: Rineka Cipta, 2009.

[18] Nurdyansyah, N., \& Fitriyani, T., Pengaruh Strategi Pembelajaran Aktif Terhadap Hasil Belajar Pada Madrasah Ibtidaiyah. Universitas Muhammadiyah Sidoarjo. 2018.

[19] Rusman, Belajar dan Pembelajaran Berbasis Komputer. Bandung: Alfabeta. 2013.

[20] Sanjaya, W., Perencanaan dan Desain Sistem Pembelajaran. Kencana. 2015.

[21] Sumarmo, Berpikir dan Disposisi Matematik Serta Pembelajarannya. Bandung: Jurusan Pendidikan Matematika UPI, 2013.

[22] Sutikno, M. S., \& Fathurrohman, P., Strategi Belajar Mengajar Melalui Penanaman Konsep Umum \& Konsep Islami. Bandung: Refika Aditama. 2010.

[23] Thorell, L., B., Lindquist, S., Nutley, S. B, Bohlin, G., \& Klingberg, T., Training And Transfer Effects Of Executive Functions In Preschool Children. Developmental Science, Vol.12 No.1, 2009. pp.106-113.

[24] Wahyuni, A., Analisis Kesulitan Mahasiswa Pada Materi Pertidaksamaan Dalam Nilai Mutlak. EkuivalenPendidikan Matematika, Vol.30 No.3. 2017.

[25] Sugiyono, Metode Penelitian Pendidikan Pendekatan Kuantitatif, Kualitatif dan R\&D. Bandung: Alfabeta, 2018

[26] D Suhaedi, E Harahap, Membangun Kemampuan Komunikasi Matematis Siswa melalui Lesson Study: Sebuah Perspektif, Jurnal Matematika, Vol. 17., No. 1., 2018.

[27] E Latipah, E Afriansyah, Analisis Kemampuan Koneksi Matematis Siswa Menggunakan Pendekatan Pembelajaran CTL dan RME, Jurnal Matematika, Vol. 17., No. 1., 2018.

[28] I Nur'aini, E Harahap, F Badruzzaman, D Darmawan, Pembelajaran Matematika Geometri Secara Realistis Dengan GeoGebra, Jurnal Matematika, Vol. 16., No. 2., 2017. 